\title{
On yield stress of compacted clays
}

\author{
Zia ur Rehman ${ }^{1 *}$, Usama Khalid $^{2,3}$, Khalid Farooq $^{4}$ and Hassan Mujtaba ${ }^{4}$
}

\author{
*Correspondence: \\ engr.zrehman@gmail.com; \\ lei-m16@mails.tsinghua. \\ edu.cn \\ ${ }^{1}$ State Key Laboratory \\ of Hydroscience \\ and Engineering, Tsinghua \\ University, Beijing, China \\ Full list of author information \\ is available at the end of the \\ article
}

\begin{abstract}
Artificial compaction is a commonly practiced ground improvement technique around the world. Yield stress is an important parameter to quantify and analyze the strength and compressibility behavior of the artificially compacted clays; such materials are indeed of practical significance in various projects, e.g., engineered landfills, clay liners, etc. The present study aims to investigate the influence of different geotechnical characteristics of compacted clays of wide plasticity range on the compaction induced yield stress, and also to develop the correlational models to quickly predict the yield stress. Three natural clayey soil samples of different geotechnical properties were collected from different sites; 27 more samples of varying index properties were prepared by mixing bentonite with natural soil samples at varying rates. Series of one-dimensional consolidation tests were performed to determine compressibility parameters like yield stress, compression index, and coefficient of volume compressibility. Atterberg's limits, grain size, compaction characteristics, and compressibility have a significant influence on the compaction induced yield stress. Predictive models of yield stress are also developed by using the plasticity index, optimum water content, and maximum dry unit weight as independent variables. Moreover, developed models are validated based on the independent data.
\end{abstract}

Keywords: Clay-bentonite mixture, Yield stress, Compaction, Compressibility, Correlation

\section{Introduction}

The shear strength and compressibility are considered to be the two most necessary characteristics of a cohesive soil mass in the design and analysis of many civil engineering structures like dams, highways, embankments, and foundations. Among these, compressibility is the most significant characteristics, for the evaluation of the settlement of soil under the overburden or load of an infrastructure [1]. In the settlement analysis, there are two crucial consideration one is the compressibility of soil, which is the measure of the volumetric change response of the soil mass under the load, and other is the past pressure that soil mass has undergone. Obviously, having experienced high past pressure leads to lesser consolidation settlement and higher shear strength of the soil mass; such soil mass is termed as over-consolidated soil. Therefore, achieving high past pressure or over-consolidation is always desirable to reduce the subsidence or consolidation settlement of the soil mass in the future, through different ground improvement techniques.

In earthwork construction, artificial compaction methods are in common practice around the world to achieve the over-consolidation. Compaction is a technique 
through which soil particles are packed closely by applying dynamic/static compression energy, which consequently decreases the compressibility, increases the shear strength, and reduces the permeability of the soils $[2,3]$. Moreover, pragmatically, the earthen materials used in the construction of different projects are diversified; it can include low to high plastic clayey soils depending on various factors, including project specification, availability of materials and economic considerations. For example, geotechnical structures such as clay liners and high-level radioactive waste repositories require high plastic clays to be compacted for the formation of earth fill barriers $[4,5]$. According to clay barriers design criteria, hydraulic conductivity, swelling, compressibility, and strength are the four essential characteristics to be considered [6]. These characteristics depend upon the mineralogy, compaction effort, and gradation of clays [4, 7]. Consequently, to avoid failure of these barriers, after placement, field compaction control of the borrow materials is essential. Moreover, the coarse material is commonly used as a base soil in the construction of different infrastructures such as railway formations, road embankments, river dykes. However, the availability of suitable coarse material becomes difficult or expensive at some sites. Thus, in such conditions, the locally available clayey soils can be considered as the alternative backfills. Usually, the geotechnical characteristics of these clays are improved by using the additives, and the compaction is the fundamental technique to densify these stabilized materials during in situ placement [3, 8-11].

Theoretically, pre-consolidation stress is the maximum stress to which a natural soil mass in the field has been subjected in the past during its geological life time [9], or, it is the largest overburden under which the soil had been consolidated [12,13]. Whereas, artificially compacted soil mass also exhibits a characteristic termed as yield stress $\left(\sigma_{y}\right)$, similar to the pre-consolidation stress exhibited by the natural soil [9]. In the construction of earthen embankment, earthen dams, engineered landfills, pavements, and also for ground improvement, this induced yield stress becomes vital for the settlement analysis of compacted soil mass or structures founded on such engineered land fills. In fact, yield stress is the quantitative parameter to examine the performance of the artificially compacted soil mass against failure and consolidation settlement.

As pre-consolidation stress $\left(\sigma_{p}\right)$, induced yield stress is also estimated through the onedimensional consolidation test like other compressibility parameters such as coefficient of compressibility $\left(a_{v}\right)$, compression index $\left(C_{c}\right)$, and co-efficient of volume compressibility $\left(m_{v}\right)$ [14]; whereas, one-dimensional consolidation test is expensive, laborious and tedious test. Therefore, it is desirable to investigate the different factors influencing compaction induced yield stress and to develop a quick mechanism to predict the compaction induced yield stress. There are many factors which can affect the yield stress like unit weight, water content, Atterberg's limits, and grain size. However, modest data is available on these influencing factors in the past literature. Prakash et al. [9] only discussed the effect of dry unit weight and water content on yield stress. Therefore, further investigation is required on the influencing factors of yield stress.

Keeping in view the feasibility of the usage of diversified compacted clayey soils in the fields and scarcity of literature on the induced yield stress behavior of such clays, the objectives of the present study are: (1) to investigate the yield stress behavior against grain size, Atterberg's limits, compaction characteristics, and compressibility of low 
to high plastic clayey soils; (2) to develop the reliable correlational models of the yield stress using basic soil characteristics of clayey soils.

\section{Materials and methodology}

For this study, three natural clayey materials L-0-1, N-0-1, and D-0-1 were collected from three different districts of Pakistan, i.e., Lahore, Gujranwala (Nandipur), and D. G. Khan, respectively, as shown in Fig. 1. These were the disturbed samples taken from 2 to $3 \mathrm{~m}$ below the ground surface. All of the soil samples were alluvial type clays obtained from the Indus plain deposits. Lahore clay, Nandipur clay, and D.G. Khan clay are naturally deposited around the Ravi river, Chenab river and Indus river respectively. After oven drying at $104{ }^{\circ} \mathrm{C}$ for $24 \mathrm{~h}, 27$ more artificial low to high plastic clayey samples were prepared by mixing bentonite at different ratio of dry weight. Bentonite was mixed with L-0-1 sample at varying ratio such as $5 \%, 10 \%, 15 \%, 20 \%, 25 \%, 30 \%, 35 \%, 40 \%, 45 \%$, and $50 \%$ and in $\mathrm{N}-0-1$ sample bentonite was mixed at the ratio of $5 \%, 10 \%, 15 \%, 20 \%, 25 \%$, $30 \%$, and $35 \%$. Ten more artificial samples were prepared by mixing the bentonites with D- $0-1$ sample at the rate of $5 \%, 10 \%, 12 \%, 15 \%, 17 \%, 20 \%, 22 \%, 25 \%, 27 \%$, and $30 \%$. Total 30 soil samples were tested in the laboratory, and following tests were performed as per ASTM standards.

- Specific gravity test (ASTM D-854 [15]).

- Grain-size distribution analysis (ASTM D-422 [16]).

- Atterberg's limit test (ASTM D-4318 [17]).

- Standard compaction test (ASTM D-698 [18]).

- One-dimensional consolidation test (ASTM D-2435 [19]).

First three tests were performed to determine the index properties. Water pycnometer was used to determine the specific gravity of soils. Hydrometer tests were performed to find out the percentage of sand, silt, and clay contents in soil samples. The sizes of clay, silt, and sand particles used in this study are $<0.005 \mathrm{~mm}, 0.005-0.05 \mathrm{~mm}$, and

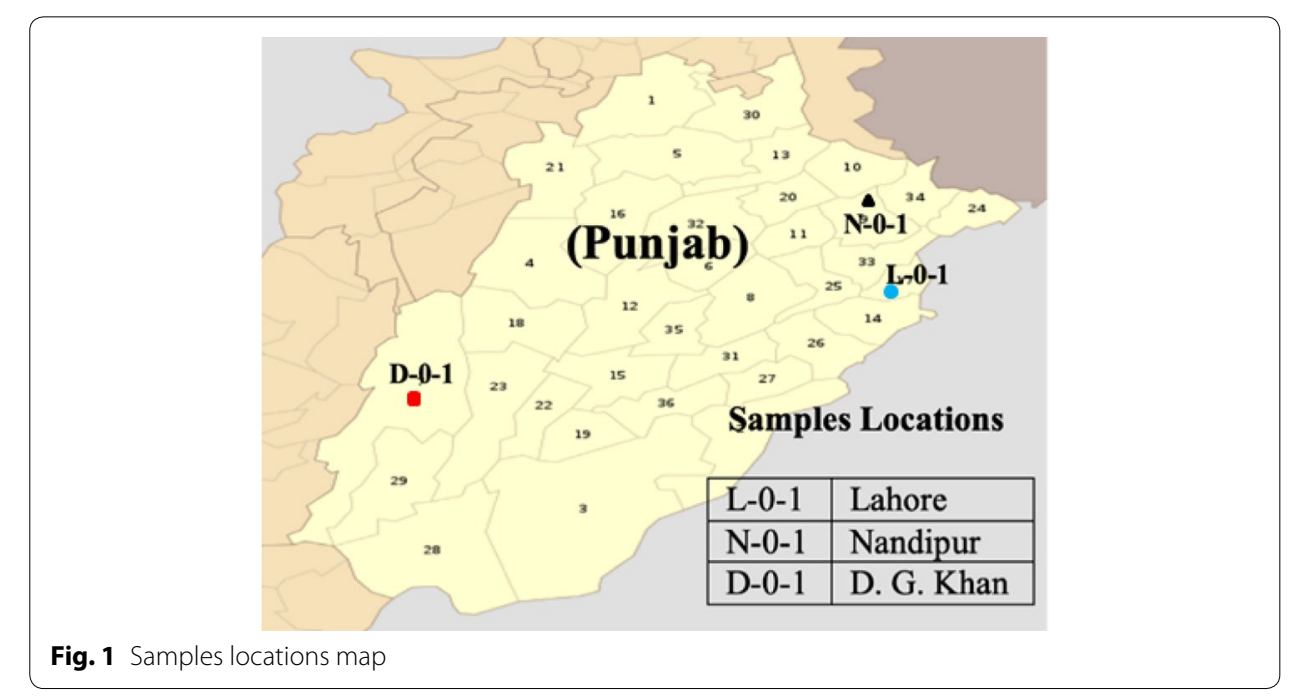




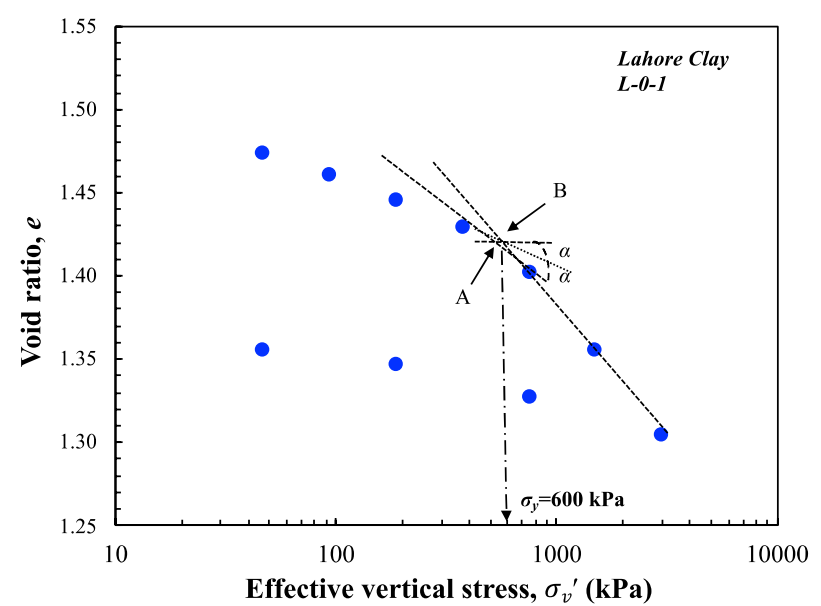

Fig. 2 Yield stress determination by using Casagrande method [12]

0.05-2 mm respectively. The liquid limit and plastic limit of samples were established according to ASTM D-4318 [17]. Samples were classified according to the Unified Soil Classification System (USCS) by using the index properties. Eight samples were classified as lean clay/low plastic clays (CL), and 22 samples were classified as fat clays/high plastic clays $(\mathrm{CH})$. Standard compaction test was used to find out the compaction characteristics of soils [20].

To perform the one-dimensional consolidation tests, soil samples were remolded at a maximum dry density $\left(\gamma_{\text {dmax }}\right)$ and optimum water content $\left(w_{\text {opt }}\right)$ determined from standard compaction test in a compaction mold. The sample was then carefully extruded in the consolidation ring, and it was ensured that the initial density and water content of soil sample in consolidation ring was same as of maximum dry density $\left(\gamma_{d \max }\right)$ and optimum water content $\left(w_{\text {opt }}\right)$ determined through standard compaction test. The method of sample preparation is designed to meet the specific objective of the present study and it is validated with the past literature $[9,21]$. Consolidation test was performed to determine the compression index, coefficient of volume compressibility, initial void ratio, and yield stress. In the consolidation test, the specimen was laterally restrained and axially loaded with stress increments. Each stress increment was applied until dissipation of pore water ceases for that stress increment. The stresses were applied double for each increment making load increment ratio (LIR) 1 . Minimum stress increment duration was taken as $24 \mathrm{~h}$ and maximum applied effective vertical $\left(\sigma_{v}{ }^{\prime}\right)$ stress was around $1600 \mathrm{kPa}$. During the consolidation test, the measurements were recorded for the change in the height of the sample.

Several methods are available in the soil mechanics literature to determine the $\sigma_{y}$ or $\sigma_{p}$ of over-consolidated soils. Some of these methods include Casagrande method [12], Burmister method [22, 23], Schmertmann method [24], the void index method [25], Janbu method [26], the method of work [27], Pacheo Silva's method [28], the log-log method [29, 30] and Jacobsen's method [31]. Casagrande method [5] is used to determine the yield stress of compacted clays explained in Fig. 2. 


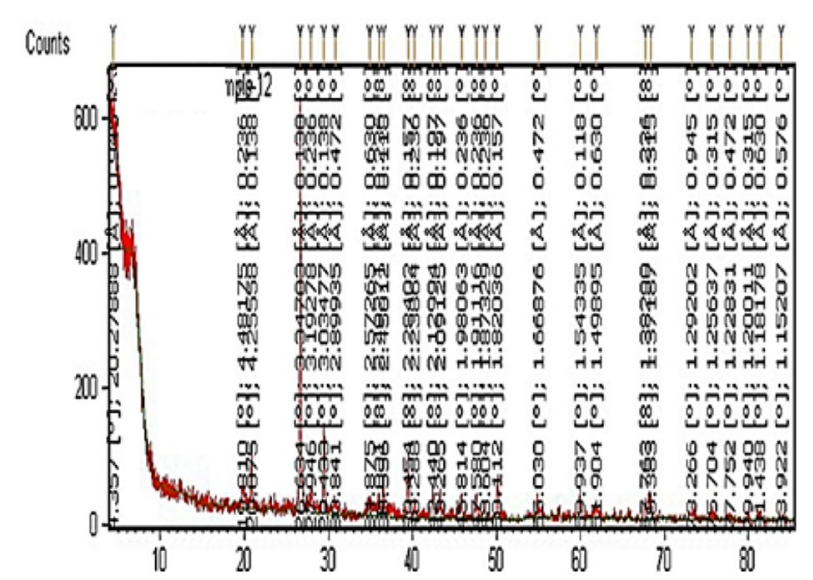

Fig. 3 Diffracting peak patterns of $x$-rays from planes of minerals for bentonite

\section{Test results}

In the present study, bentonite was used to produce the artificial clayey samples of varying plasticity. The index properties tests were also performed on pure bentonite. The liquid limit $\left(w_{L}\right)$ and plasticity index $\left(I_{P}\right)$ of bentonite are $301 \%$ and $273 \%$ respectively. The silt and clay contents were $3 \%$ and $97 \%$ respectively. The $x$-ray diffraction analysis was also carried out on the bentonite. Figure 3 shows the diffracting peak pattern and response spectrum in diffracting peak pattern of bentonite; it hints the presence of montmorillonite, kaolinite, and illite minerals.

The summary of geotechnical characteristics of all samples is presented in Table 1. Clayey samples are classified into two sub-groups, i.e., lean clay $(\mathrm{CL})$ and fat clay $(\mathrm{CH})$ as per the Unified Soil Classification System [20]. The range of specific gravity $\left(G_{s}\right)$ was recorded from 2.67 to 2.75 . The experimental results of performed tests are presented in Fig. 4. According to grain size distribution, the ranges of sand, silt and clay contents for $\mathrm{CL}$ soils are $5-7 \%, 54-72 \%$, and $21-40 \%$ respectively and for $\mathrm{CH}$ soils, the range is $2-6 \%, 26-55 \%$, and $41-72 \%$ respectively. The $w_{L}$-values vary from 30 to $49 \%$ for CL soils and 52 to $129 \%$ for $\mathrm{CH}$ soils while the $I_{P^{-}}$-values vary from 11 to $29 \%$ and 32 to $113 \%$ for $\mathrm{CL}$ and $\mathrm{CH}$ soils respectively as shown in Fig. $4 \mathrm{~b}$.

For CL soils, the ranges of $\gamma_{d \max }$ and $w_{\text {opt }}$-values are $15.32-17.43 \mathrm{kN} / \mathrm{m}^{3}$ and $14.51-$ $18.32 \%$ respectively; for $\mathrm{CH}$ soils, the $\gamma_{d \max }$ - and $w_{\text {opt }}$-values are between 14 to $16.3 \mathrm{kN} /$ $\mathrm{m}^{3}$ and 17 to $27 \%$ respectively as presented in Fig. 4c. The overall range of yield stress is 210 to $600 \mathrm{kPa}$, and it is in the range of $400-600 \mathrm{kPa}$ and $210-410 \mathrm{kPa}$ for CL soils and $\mathrm{CH}$ soils respectively, as displayed in Fig. 4c. Moreover, other compressibility parameters of the samples were also determined. The value of $C_{c}$ varies from 0.16 to 0.92 and range of $m_{v}$ is from 0.17 to $0.80 \mathrm{MPa}^{-1}$ for all soil samples (Fig. 4d). Initial void ratio falls between $0.5-0.86$ and $0.63-1.52$ for $\mathrm{CL}$ and $\mathrm{CH}$ respectively.

\section{Factors affecting the yield stress}

To determine the effect of geotechnical characteristics on yield stress, several statistical analyses were accomplished using test results. The effects of grain size, Atterberg's limits, compaction characteristics and compressibility parameters on yield stress were 


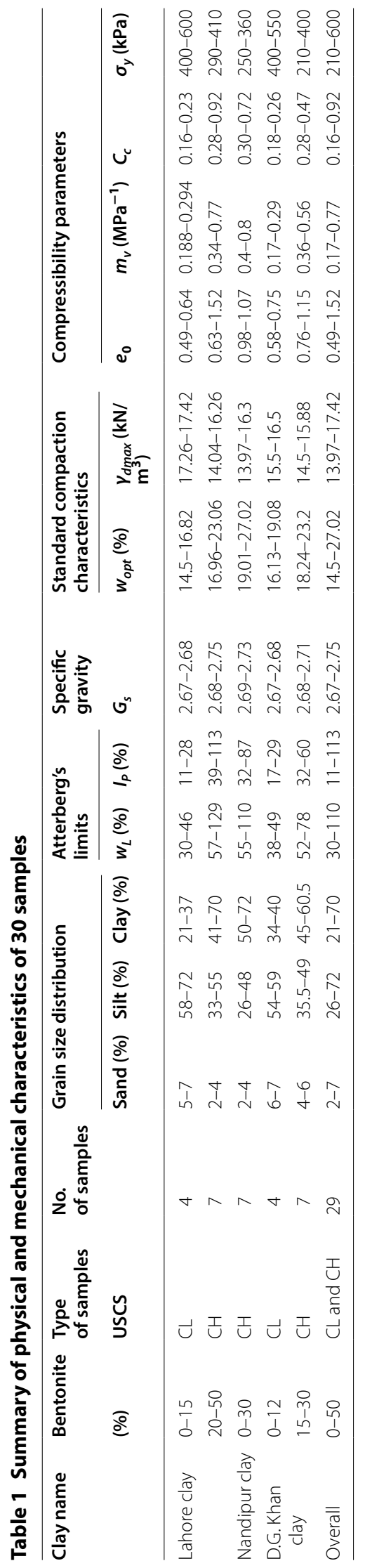



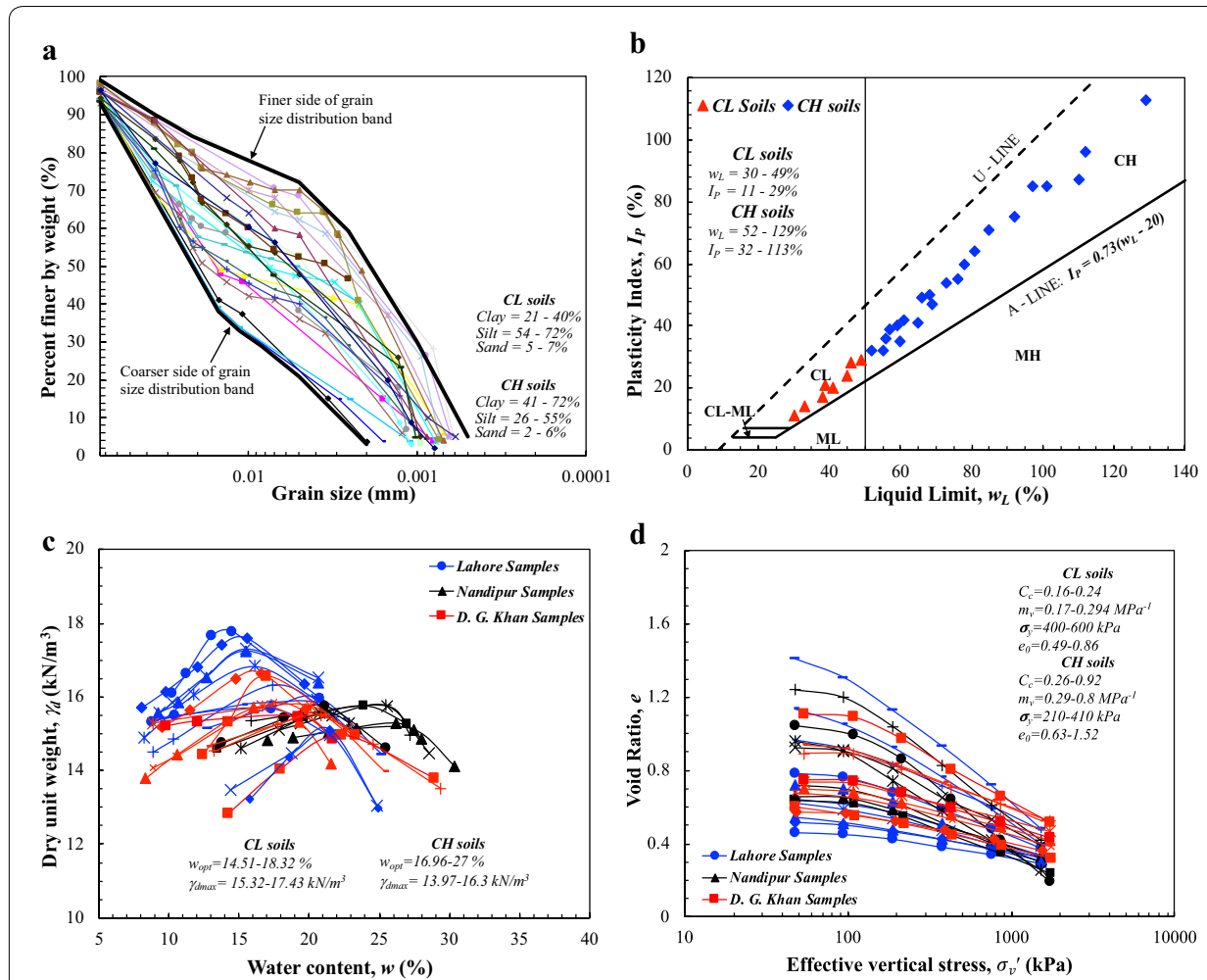

Fig. 4 Experimental results a grain size distribution curves, $\mathbf{b} w_{L} v s I_{p}, \mathbf{c}$ compaction curves, $\mathbf{d}$ compression curves

determined. Average values of aforementioned characteristics have been calculated for $\mathrm{CL}$ and $\mathrm{CH}$ soils by fixing the liquid limit ranges, and these average values are given in Table 2. Thirty clayey samples are used to fix these $w_{L}$-ranges. Plots for variation in yield stresses of clayey soils with respect to aforementioned geotechnical properties are shown in Figs. 5, 6, 7 and 8. Table 3 describes the concise summary of the behavior of $\sigma_{y}$ against the geotechnical properties.

\section{Effect of grain size on yield stress}

The behavior of $\sigma_{y}$ against clay and silt contents are established in Fig. 5a, b. The value of $\sigma_{y}$ is decreasing up to $303 \mathrm{kPa}$ with increasing clay content up to $51.5 \%$, but more increment in clay content have an insignificant effect on $\sigma_{y}$-value. The value of $\sigma_{y}$ is increasing with increasing percentage of silt content in clayey soils. Up to $45 \%$ of silt content, there is a minor change in $\sigma_{y}$-value. The compacted clayey soils with more silt content can have higher yield stress, taking all other influencing factors to be unchanged. Thus, the coarser grain fraction increases the compaction induced yield stress.

\section{Effect of Atterberg's limits on yield stress}

The $\sigma_{y}$-value is decreased with an increase in $w_{L}$ and $I_{P}$ values, as shown in Fig. 6a, b. Average values of $w_{L}$ and $I_{P}$ are $35 \%$ and $15.8 \%$ respectively at $582.5 \mathrm{kPa}$ of $\sigma_{y}$, whereas, values of $w_{L}$ and $I_{P}$ are $106.8 \%$ and $90.2 \%$ respectively at $293 \mathrm{kPa}$ of $\sigma_{y}$-value; this renders that $w_{L}$ and $I_{P}$ increased $67 \%$ and $82.5 \%$ respectively with a decrease of 


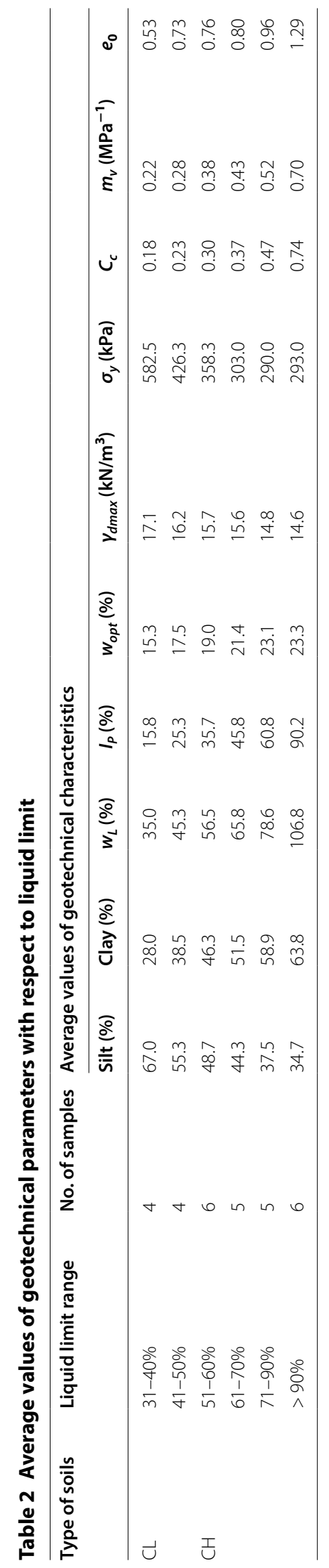



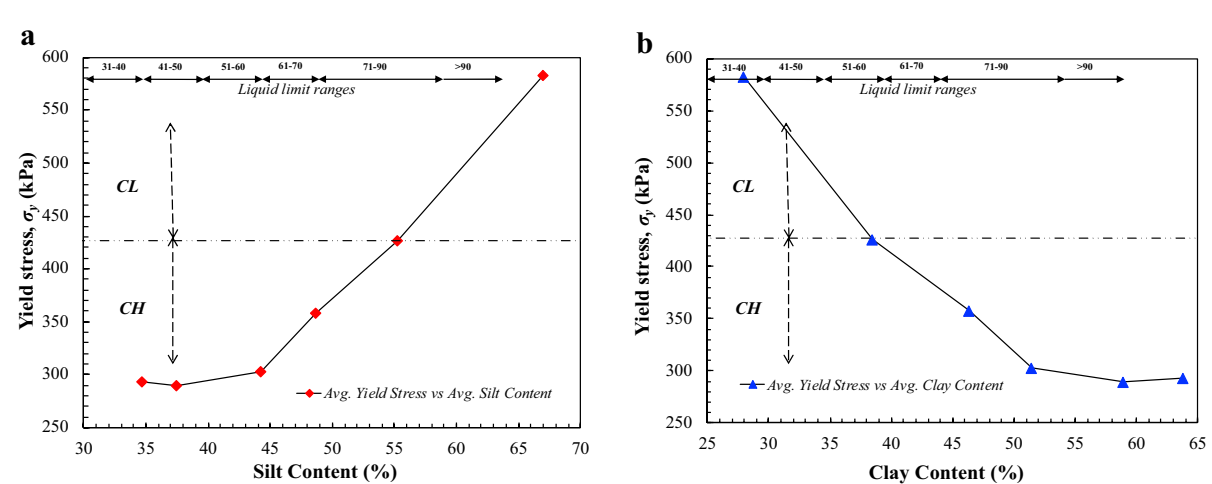

Fig. 5 Effect of soil types on yield stress. a Silt content, $\mathbf{b}$ clay content
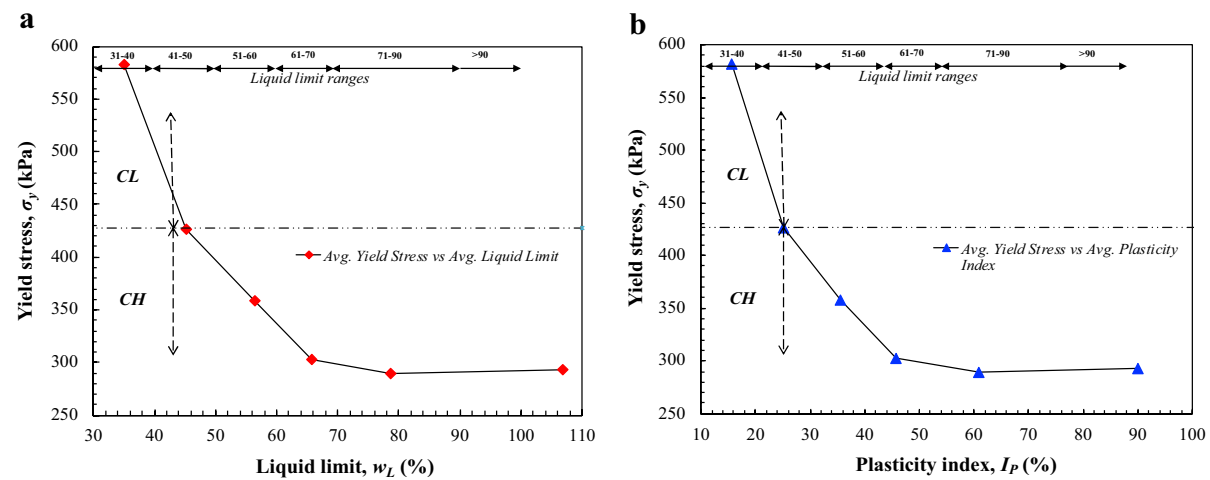

Fig. 6 Effect of Atterberg's limits on yield stress. a Liquid limit, b plasticity index
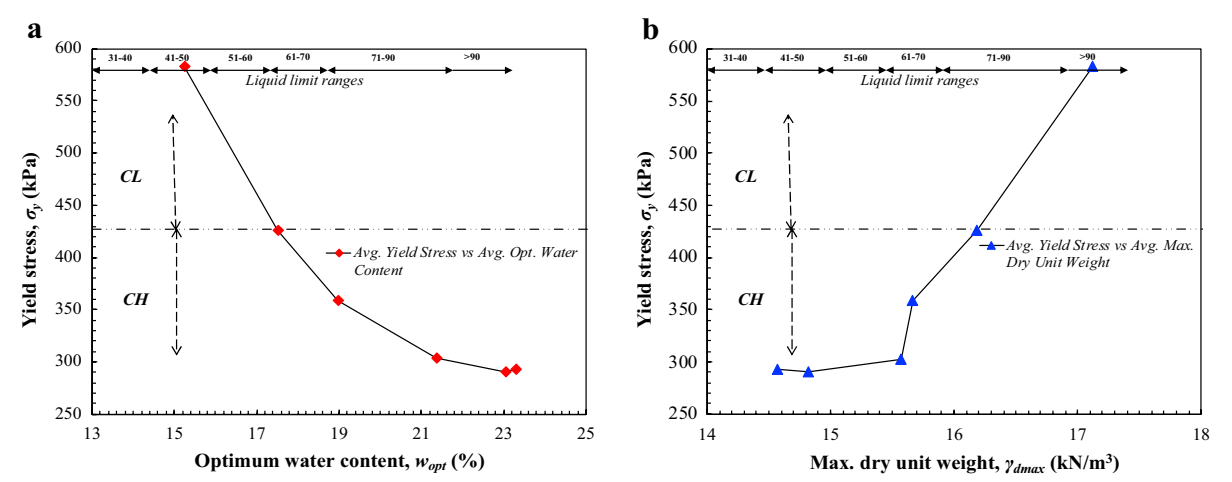

Fig. 7 Effect of compaction characteristics on yield stress. a Optimum water content, b maximum dry unit weight

$49.7 \%$ in yield stress. It is also observed that $w_{L}$ and $I_{P}$ have a significant effect on $\sigma_{y}$ up to $65.8 \%$ and $45.8 \%$ of their values respectively, beyond these values effect of Atterberg's limits on $\sigma_{y}$ become insignificant. These findings render that for the similar 

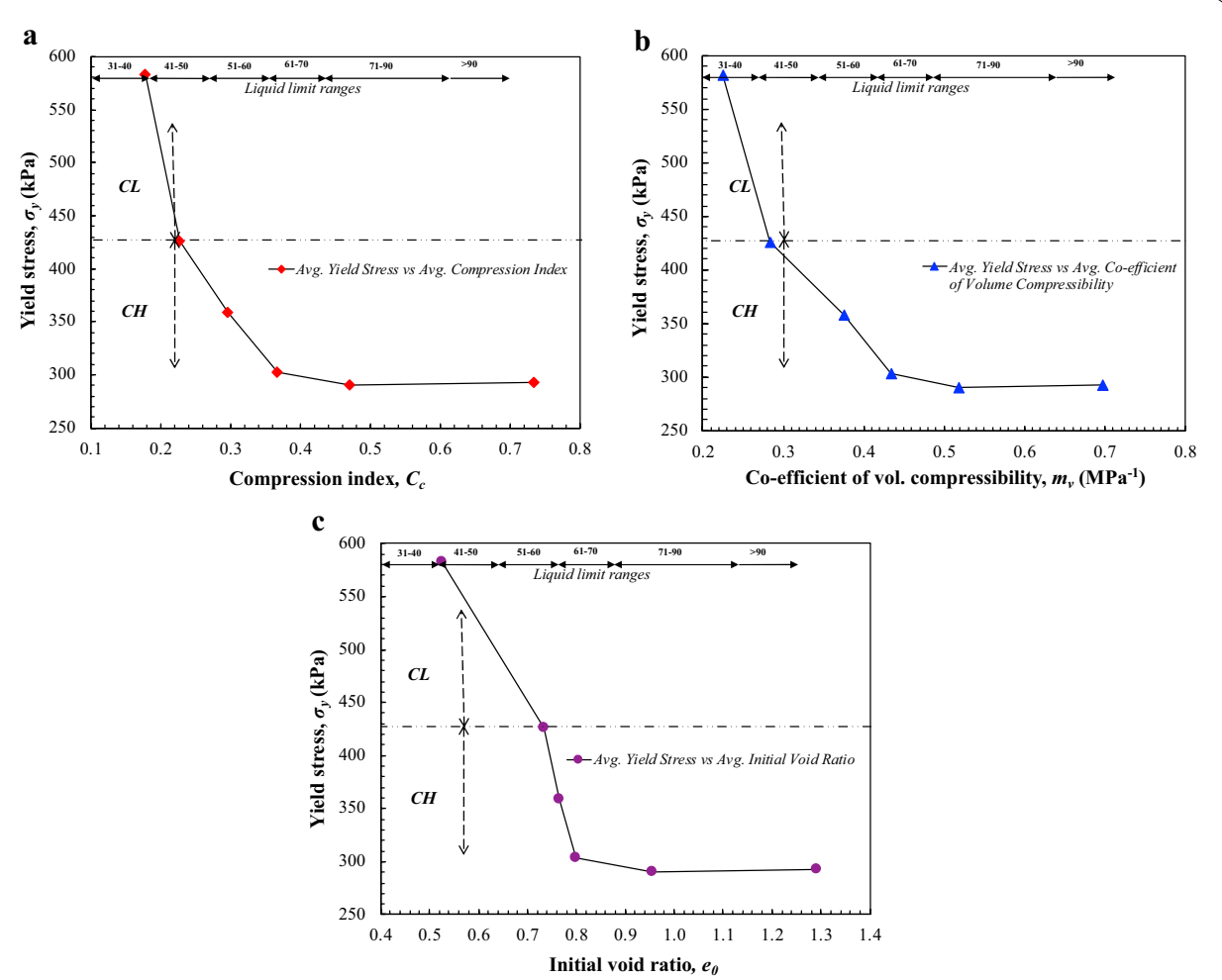

Fig. 8 Effect of compressibility parameters on yield stress. a Compression index, $\mathbf{b}$ co-efficient of volume compressibility, $\mathbf{c}$ initial void ratio

Table 3 Effect of geotechnical parameters on yield stress

\begin{tabular}{lll}
\hline Parameters & Effect on $\boldsymbol{\sigma}_{\boldsymbol{y}}$ & Reference \\
\hline Silt content & Increasing & Fig. $5 \mathrm{a}$ \\
Clay content & Decreasing & Fig. $5 \mathrm{~b}$ \\
Liquid limit $\left(w_{L}\right)$ & Decreasing & Fig. $6 \mathrm{a}$ \\
Plasticity index $\left(I_{p}\right)$ & Decreasing & Fig. $6 \mathrm{~b}$ \\
Optimum water content $\left(w_{\text {opt }}\right)$ & Decreasing & Fig. $7 \mathrm{a}$ \\
Maximum dry unit weight $\left(\gamma_{\text {dmax }}\right)$ & Increasing & Fig. $7 \mathrm{~b}$ \\
Compression index $\left(C_{c}\right)$ & Decreasing & Fig. $8 \mathrm{a}$ \\
Co-efficient of volume compressibility $\left(m_{v}\right)$ & Decreasing & Fig. $8 \mathrm{~b}$ \\
Initial void ratio $\left(e_{0}\right)$ & Decreasing & Fig. $8 \mathrm{c}$ \\
\hline
\end{tabular}

compaction effort, the compaction induced yield stress is higher for low plastic clays, because of the fact that it is easier to achieve tighter grain matrix for low plastic clays due to low moisture and less void ratio induced by diffused double layer and clay mineral interaction. 


\section{Effect of compaction characteristics on yield stress}

Figure 7 explains the behavior of $\sigma_{y}$ with respect to the compaction characteristics. With increasing the $w_{\text {opt }}$, the $\sigma_{y}$-value is decreased as shown in Fig. 7a. The value of $w_{\text {opt }}$ is increased from 15.3 to $23.3 \%$ while the value of $\sigma_{y}$ is decreased from 582.5 to $294 \mathrm{kPa}$. Moreover, with an increase in the $\gamma_{d \max }$-value from 15.6 to $17.1 \mathrm{kN} / \mathrm{m}^{3}$, the $\sigma_{y}$ is also increased from 303 to $582.5 \mathrm{kPa}$, as presented in Fig. 7b. However, there is an insignificant change in the $\sigma_{y}$-value when the $\gamma_{d \max }$-value is increased from 14.6 to $15.6 \mathrm{kN} / \mathrm{m}^{3}$. Hence, $14.6 \mathrm{kN} / \mathrm{m}^{3}$ can be taken as influence extent of $\gamma_{d \max }$. These findings demonstrate that improving the compaction quality improves the compaction induced yield stress.

\section{Effect of compressibility parameters on yield stress}

Figure 8 presents the effect of compressibility parameters on yield stress. The $\sigma_{y}$ shows a similar trend against the compressibility index $\left(C_{c}\right)$, the coefficient of volume compressibility $\left(m_{v}\right)$ and the initial void ratio $\left(e_{0}\right)$. The $\sigma_{y}$-value is decreased rapidly up to the $w_{L}=60 \%$ with an increase in the values of $C_{c}, m_{v}$, and $e_{0}$; beyond which, these compressibility parameters do not exhibit any significant impact on the $\sigma_{y}$. It can be concluded that for same compaction effort, compaction induced yield stress is lower for more compressible soil.

\section{Development of correlations}

This study also included the development of predictive models of yield stress. For this purpose, a dataset of the aforementioned 30 soil samples was used. Plasticity index $\left(I_{P}\right)$, optimum water content $\left(w_{\text {opt }}\right)$ and maximum dry unit weight $\left(\gamma_{\text {dmax }}\right)$ were selected as the independent variables, and $\sigma_{y}$ is used as the dependent variable. Power regression analyses were executed on the data and dependence of $\sigma_{y}$ on $I_{P}, w_{\text {opt }}$ and $\gamma_{d \max }$ are presented in Fig. 9a-c; the developed correlations are exhibited in Eqs. (1), (2), and (3).

$$
\begin{aligned}
& \sigma_{y}(\mathrm{kPa})=1443.3\left(I_{P}\right)^{-0.382} \\
& \sigma_{y}(\mathrm{kPa})=25,220\left(w_{\text {opt }}\right)^{-1.431} \\
& \sigma_{y}(\mathrm{kPa})=0.0143\left(\gamma_{\text {dmax }}\right)^{3.682}
\end{aligned}
$$

The values of correlation coefficient $\left(R^{2}\right)$ for Eqs. (1), (2), and (3) are $0.63,0.77$, and 0.62 respectively. The maximum $R^{2}$-value is 1 , and a good and reliable model must have a high $R^{2}$-value. The $R^{2}$ is an index of the goodness of fit between the predictive model and sample data used to develop that model [2]. It provides a quantitative 

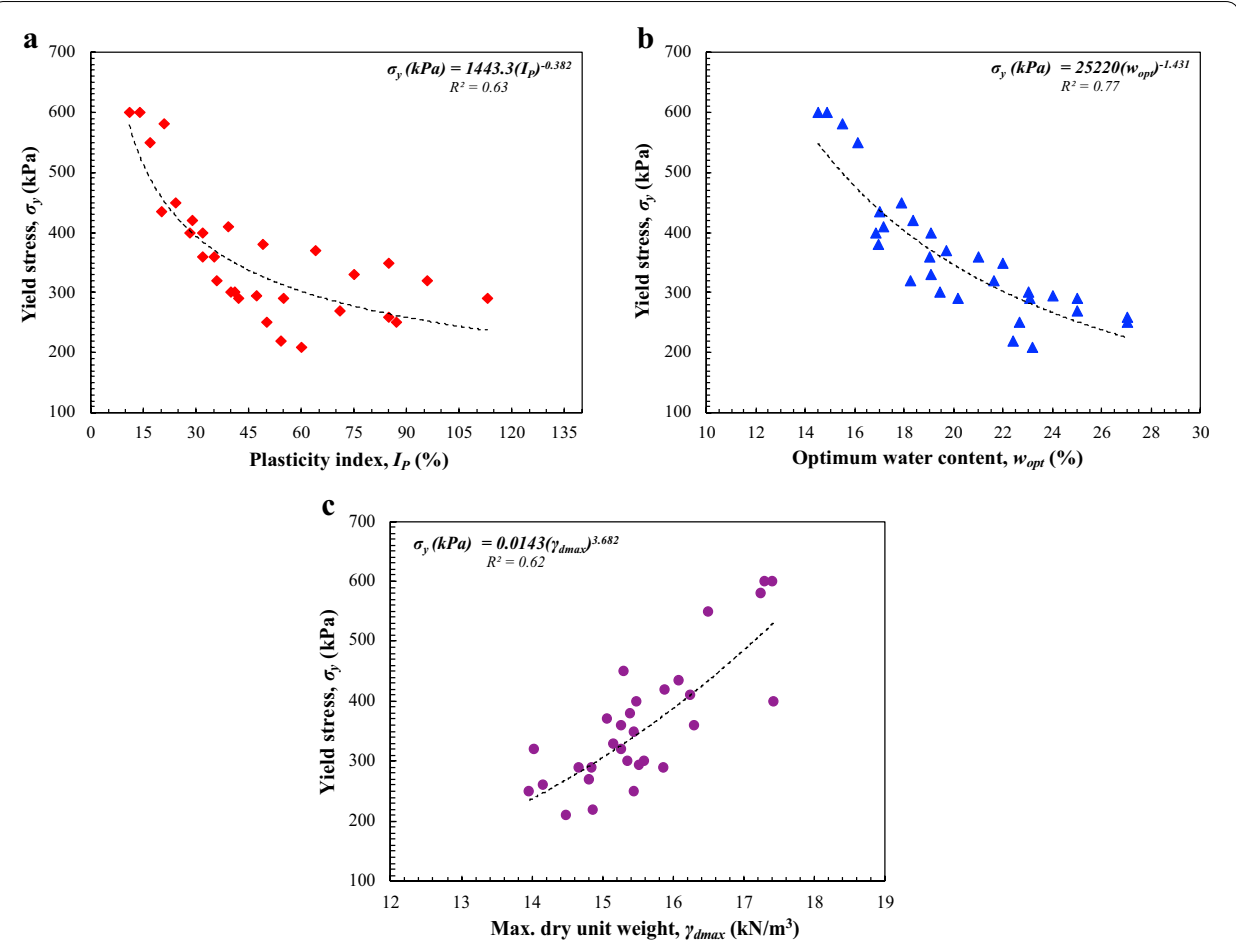

Fig. 9 Correlation models. a $\sigma_{y}$ Vs. $I_{p}, \mathbf{b} \sigma_{y}$ Vs. $W_{\text {opt }}$ c $\sigma_{y}$ Vs. $\gamma_{\text {dmax }}$

index of association between measured and predicted values, and is used as a measure of accuracy for future predictions [10]. For $\sigma_{y}$ models, the $R^{2}$-value of the Eq. (2) is 0.77 , which is greater than the other two equations. It means the dependence of $\sigma_{y}$ on $w_{\text {opt }}$ is more than $I_{P}$ and $\gamma_{d m a x}$.

The accuracy of the proposed models was checked against the data used to develop these models. Percentage deviation from $45^{\circ}$-line (called equality line), which is also referred to as the percentage error of the predictive models was calculated by the given formula;

$$
\operatorname{Error}(\%)=\frac{100}{n} \sum_{t=1}^{n}\left(\frac{A_{t}-P_{t}}{A_{t}}\right)
$$

where, $A_{t}=$ actual value, $P_{t}=$ predicted value and $n=$ number of values. Moreover, the percentage error of the model is calculated based on data used for the development of correlation, in this stage. Figure 10 presents the plot of experimental $\sigma_{y}$-values versus $\sigma_{y}$-values predicted using the developed models. For $\sigma_{y}$, percentage errors in Eqs. (1), (2), and (3) are $\pm 9 \%, \pm 7.8 \%$, and $\pm 9.8 \%$ respectively, as shown in Fig. 10. Minimum percentage error was found to be $\pm 7.8 \%$ for Eq. (2), for this reason, $\pm 7.8 \%$ is taken as a confidence interval for $\sigma_{y}$-models validity. 


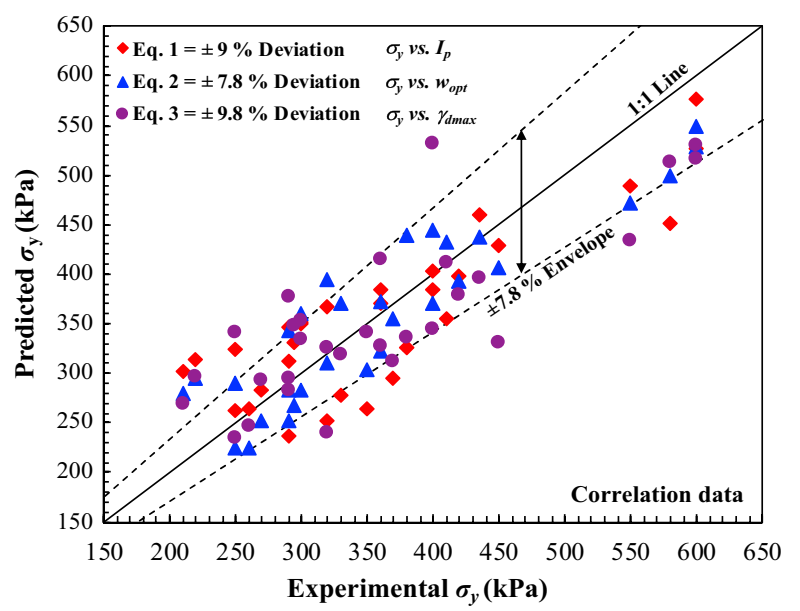

Fig. 10 Validation of yield stress correlations using correlations data

\section{Validation of correlations}

The last step in the establishment of any predictive model is to validate the model based on independent data, which is not being included in the development of the model. For this purpose, the required geotechnical characteristics of the six samples were obtained, as presented in Table 4. The sketch was drawn between experimental and predicted values of yield stress, as presented in Fig. 11. To check and compare the accuracy of these three models, $\pm 7.8 \%$ error envelope is drawn in Fig. 11. Percentage errors in Eqs. (1), (2), and (3) are $\pm 9.2 \%, \pm 7.5 \%$, and $\pm 10.5 \%$ respectively. It is noted that one out of six data points falls outside the standardized envelope for all three equations (Fig. 11). The Eq. (2) demonstrates the minimum percentage error as compared to others. It is worth mentioning here that based on statistical indicators Eq. (2) is comparatively proved to be the most effective one in the prediction of $\sigma_{y}$ among all three models. However, if it is desirable to avoid the compaction test for the prediction of $\sigma_{y}$-value, Eq. (1) can prove to be effective. Moreover, all three equations can reliably be used to predict the yield stress of clayey samples based on available data.

\section{Conclusions}

This study presents predictive models of yield stress $\left(\sigma_{y}\right)$ and effect of geotechnical characteristics on yield stress. The following conclusions are drawn on the basis of this research:

1. With increasing the clay content, liquid limit, plasticity index, optimum water content, compressibility index, coefficient of volume compressibility and initial void ratio, the yield stress $\left(\sigma_{y}\right)$ is decreased while with increasing the silt content and maximum dry unit weight, the yield stress is increased. Moreover, the effect of these so- 


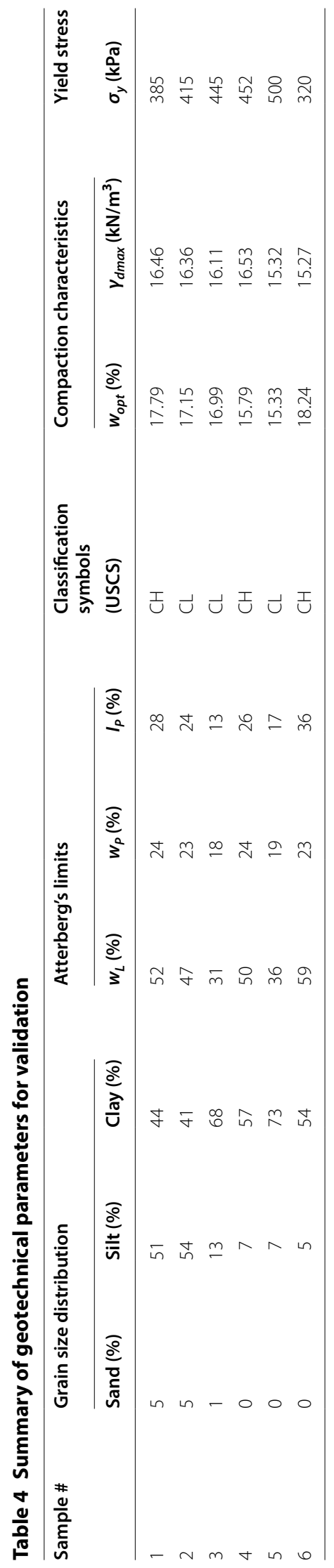




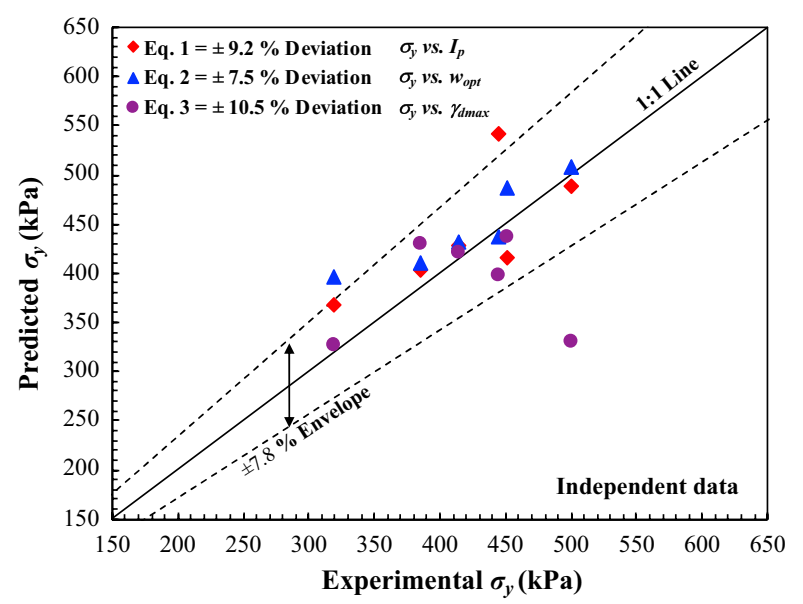

Fig. 11 Validation of yield stress correlations using independent data

called influencing factors on yield stress becomes insignificant after certain limits, which can be termed as influence extents.

2. Three predictive models of yield stress are also proposed by using plasticity index, optimum water content and maximum dry unit weight as independent variables with reliable prediction accuracy.

3. The developed models are more valid for the ranges of $I_{p}, w_{o p t}$, and $\gamma_{d}$ to be around $11-113 \%, 14.5-27 \%$, and $13.97-17.42 \mathrm{kN} / \mathrm{m}^{3}$ respectively.

\section{Authors' contributions}

ZR designed and executed the laboratory test plan, developed the empirical models, and drafted the manuscript. UK analyzed the test results, checked the validity of empirical models and presented the discussion along with illustrative examples in the manuscript. KF and HM provided the guidance and suggestions to improve this study. All authors read and approved the final manuscript.

\section{Author details}

${ }^{1}$ State Key Laboratory of Hydroscience and Engineering, Tsinghua University, Beijing, China. ${ }^{2}$ State Key Laboratory of Ocean Engineering, Shanghai Jiao Tong University, Shanghai, China. ${ }^{3}$ Department of Civil Engineering, COMSATS University Islamabad, Sahiwal, Pakistan. ${ }^{4}$ Department of Civil Engineering, University of Engineering and Technology, Lahore, Pakistan.

\section{Competing interests}

The authors declare that they have no competing interests.

\section{Publisher's Note}

Springer Nature remains neutral with regard to jurisdictional claims in published maps and institutional affiliations.

Received: 11 April 2017 Accepted: 22 November 2018

Published online: 12 December 2018

\section{References}

1. Tiwari BT, Ajmera B (2012) New correlation equations for compression index of remoulded clays. J Geotech Geoenviron Eng 138(6):757-762

2. Farooq K, Khalid U, Mujtaba H (2016) Prediction of compaction characteristics of fine-grained soils using consistency limits. Arab J Sci Eng 41(4):1319-1328

3. Khalid U, Rehman ZU (2018) Evaluation of compaction parameters of fine-grained soils using standard and modified efforts. Int J Geo Eng 9(15):1-17. https://doi.org/10.1186/s40703-018-0083-1

4. Bohnhoff GL, Shackelford CD (2014) Consolidation behaviour of polymerized bentonite-amended backfills. J Geotech Geoenviron Eng 140(5):040130

5. Dafalla MA (2017) The compressibility and swell of mixtures for sand-clay liners. Adv Mater Sci Eng. https://doi. org/10.1155/2017/3181794 
6. Li X, Cai G, Puppala AJ, Liu S (2018) Compression behaviour of reconstituted soils mixed with bentonite for a cutoff wall in a landfill site. Environ Earth Sci 77:390. https://doi.org/10.1007/s12665-018-7572-6

7. Faseel SK, Shahid A, Mavinakere ER, Ryan C (2014) Compressive strength of compacted clay-sand mixes. Adv Mater Sci Eng. https://doi.org/10.1155/2014/921815

8. Khalid U, Liao CC, Ye G-L, Yadav SK (2018) Sustainable improvement of soft marine clay using low cement content: a multi-scale experimental investigation. Constr Build Mater 166:634-646. https://doi.org/10.1016/j.conbuildma t.2018.10.034

9. Prakash K, Sridharan A, Prasanna HS (2014) Compaction induced yield stress. Geotech Geol Eng 32:311-319

10. Rehman ZU, Khalid U, Farooq K, Mujtaba H (2017) Prediction of CBR value from index properties of different soils. Technic J 22(2):17-26

11. Kodikara J, Islam T, Shounthrarajah A (2018) Review of soil compaction: history and recent developments. Transp Geotech. https://doi.org/10.1016/j.trgeo.2018.09.006 (in Press)

12. Casagrande A (1936) The determination of the pre-consolidation load and its practical significance. In: Proceedings of 1st international soil mechanics and foundation engineering conference, vol 3, Cambridge, pp 60-64

13. Kulhawy FH, Mayne PW (1990) Manual on estimating soil properties for foundation design, Rpt. EL-6800. Electric Power Research Inst. Palo Alto

14. Bowles JE (1996) Foundation analysis and design, 5th edn. Mc Graw-Hill Book Company Inc., New York

15. ASTM D 854-00 (2002) Standard test method for specific gravity of soil solids by water pycnometer. Annual book of ASTM Standards 04(08)

16. ASTM D 422 (2002) Standard test method for particle-size analysis of soils. Annual Book of ASTM Standards 04(08)

17. ASTM D 4318 (2000) Standard test methods for liquid limit, plastic limit, and plasticity index of soil. Annual Book of ASTM Standards 04(08)

18. ASTM, D 698 (2000) Test methods for laboratory compaction characteristics of soil using standard effort $(12,400$ $\left.\mathrm{ft}-\mathrm{lbf} / \mathrm{ft}^{3}\left(600 \mathrm{kN}-\mathrm{m} / \mathrm{m}^{3}\right)\right)$. Annual Book of ASTM Standards 04(08)

19. ASTM, D 2435 (2011) Standard test methods for one-dimensional consolidation properties of soils using incremental loading. Annual Book of ASTM Standards 04(08)

20. ASTM D 2487 (2487) Standard practice for classification of soils for engineering purposes (Unified Soil Classification System). Annual Book of ASTM Standards 04(08)

21. Oualmakran M, Mercatoris BCN, François B (2016) Pore-size distribution of a compacted silty soil after compaction, saturation, and loading. Can Geotech J 53(12):1902-1909

22. Burmister DM (1942) Laboratory investigations of soils at flushing meadow park. Transactions ASCE:107-187

23. Burmister DM (1951) The application of controlled test methods in consolidation testing. Symp Consol Test Soils ASTM 126:83-89

24. Schemertmann JM (1955) The undisturbed consolidation of clay. Trans ASCE 120:1201-1211

25. Burland JB (1990) On the compressibility and shear strength of natural clays. Geotechnique 29:329-378

26. Janbu N (1969) The resistance concept applied to deformation of soils. In: Proce 7th Int Soil Mech Found Eng Conf 01, pp 191-196

27. Becker DE, Crooks JHA, Been K, Jefferies MG (1987) Work as criterion for determining in situ and yield stresses in clays. Can Geotech J 24:549-564

28. Clementino RV (2005) Discussion of an oedometer test study on the preconsolidation stress of glaciomarine clays. Can Geotech J 40:857-872

29. Sridharan A, Abraham BM, Jose BT (1991) Improve technique for estimation of preconsolidation pressure. Geotechnique $41(2): 263-268$

30. Jose BT, Sridharan A, Abraham BM (1989) Log-log method for determination of pre-consolidation pressure. Geotech Test J ASTM 12(3):230-239

31. Jacobsen HM (1992) Bestemmelse of forbelasting stryk laboratorict. IT in nordiske geotekiker mode, vol 2. NGM-92, Aalborg, pp 455-460

\section{Submit your manuscript to a SpringerOpen ${ }^{\circ}$ journal and benefit from:}

- Convenient online submission

- Rigorous peer review

- Open access: articles freely available online

- High visibility within the field

Retaining the copyright to your article

Submit your next manuscript at $\gg$ springeropen.com 